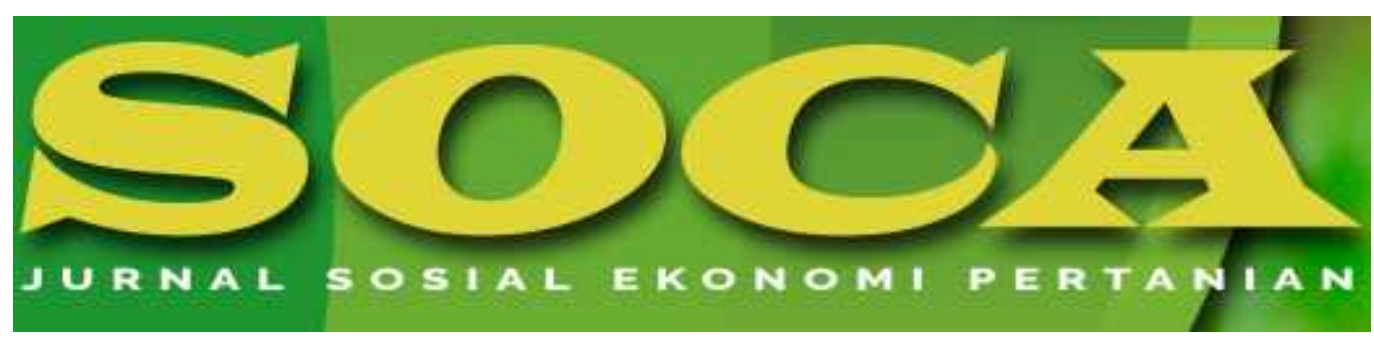

https://ojs.unud.ac.id/index.php/soca

\title{
KINERJA SOSIAL LEMBAGA KEUANGAN MIKRO AGRIBISNIS (LKM-A) DI KECAMATAN DAWE, KABUPATEN KUDUS
}

\author{
Maqsul Mahsufah, Siwi Gayatri dan Tutik Dalmiyatun \\ Program Studi Agribisnis, Fakultas Peternakan dan Pertanian Universitas Diponegoro \\ Jalan Prof. Soedarto Kampus Tembalang, Semarang, 50275 \\ Email Korespondensi:mahsufah.95@gmail.com,gayatri.siwi@gmail.com, \\ tdalmiyatun@gmail.com,Telepon/HP:085641533652,085225843307,085727141126
}

Kata Kunci:
kinerja sosial,
pendapatan
usaha,
Lembaga
Keuangan
Mikro
Agribisnis
(LKM-A)

Kata Kunci: kinerja sosial, pendapatan

usaha,

Lembaga

Keuangan

Agribisnis

(LKM-A)

\begin{abstract}
Abstrak
Kementerian Pertanian melalui program Pengembangan Usaha Agribisnis Perdesaan (PUAP) diharapkan mampu mengurangi kemiskinan dan pengangguran di perdesaan melalui pengembangan Lembaga Keuangan Mikro Agribisnis (LKM-A). Peran LKM-A yaitu membantu memfasilitasi petani di perdesaan dalam memperoleh modal usaha untuk membiaya usaha agribisnisnya. Namun, dalam pelaksanaanya LKM-A masih belum mampu berkembang secara maksimal. Penelitian tentang kinerja sosial LKM-A bertujuan untuk menganalisis kinerja sosial, pendapatan usaha LKM-A dan hubungan antara kinerja sosial dengan pendapatan usaha LKM-A di Kecamatan Dawe, Kabupaten Kudus. Penelitian ini dilaksanakan pada tanggal 12 Februari - 5 April 2018 di Kecamatan Dawe, Kabupaten Kudus. Metode yang digunakan dalam penelitian adalah metode survei. Penentuan sampel menggunakan metode sensus dengan seluruh LKM-A yang ada di Kecamatan Dawe yang berjumlah 18 dijadikan sebagai obyek penelitian. Teknik analisis data menggunakan statistika non-parametrik korelasi Spearman. Kinerja sosial dianalisis menggunakan pendekatan MIX Market Social Performance Standart dengan mengambil 16 indikator. Hasil penelitian menunjukkan bahwa dari 16 indikator kinerja sosial hanya 3 indikator dalam kriteria sedikit berkembang (0$50 \%$ ) yaitu indikator sumber modal, rasio peminjam perempuan dan rasio peminjam rumah tangga miskin. Pendapatan usaha LKM-A dalam kriteria tidak berkembang. Tidak terdapat hubungan yang signifikan antara variabel kinerja sosial dengan pendapatan usaha LKM-A.
\end{abstract}


SOCIAL PERFORMANCE OF AGRIBUSINESS MICROFINANCE INSTITUTIONS (LKM-A) IN DAWE DISTRICT, KUDUS REGENCY

\begin{tabular}{l}
\hline Keywords: \\
social \\
performance, \\
revenue \\
generating, \\
Agribusiness \\
Microfinance \\
Institutions \\
(LKM-A) \\
\hline
\end{tabular}

How to Cite (APA 6th Style):

Mahsufah, M., Gayatri, S., \& Tutik Dalmiyatun. (2019). Kinerja Sosial Lembaga Keuangan Mikro Agribisnis (LKM-A) di Kecamatan Dawe, Kabupaten Kudus. SOCA: Jurnal Sosial Ekonomi Pertanian, 13(3), 420-432. https://doi.org/https://doi.org/10.24843/SOCA.2019.v13.i03.p11

\section{PENDAHULUAN}

Sektor pertanian masih menjadi salah satu sektor utama yang dikembangkan masyarakat perdesaan untuk menghasilkan pendapatan. Namun, usaha pertanian yang dilakukan masih terhambat oleh permodalan, pasar dan teknologi serta kelembagaan pertanian yang masih lemah. Menurut Herwinarni dan Hariyanto (2011), usaha tani termasuk dalam kategori usaha yang tidak bankable karena tidak memenuhi kualifikasi analisis kredit/pembiayaan yang dikenal 5C yakni character (watak), collateral (jaminan kredit/agunan), capacity (kemampuan manajemen), capital (ketersediaan modal sendiri) dan condition (kondisi keuangan/ekonomi). Usaha tani kesulitan dalam mendapatkan modal dari lembaga keuangan formal sehingga petani memanfaatkan dana seadanya yang berakibat tidak optimalnya produktivitas dan pendapatan tidak meningkat. Oleh karena itu, pada tahun 2008 
pemerintah mengeluarkan program Pengembangan Usaha Agribisnis Perdesaan (PUAP) untuk menanggulangi kemiskinan dengan cara mengembangkan usaha agribisnis perdesaan.

Kementerian Pertanian telah melaksanakan Program PUAP dari tahun 2008 - 2015 dengan menyalurkan dana Bantuan Langsung Masyarakat (BLM) sebesar Rp. 100 juta kepada petani melalui Gapoktan PUAP yang digunakan untuk penguatan modal usaha. Dana yang telah disalurkan sebesar Rp. 5,2 Triliun kepada 52.186 Gapoktan/desa di 34 provinsi di seluruh Indonesia (Kementerian Pertanian, 2016).

Strategi pelaksanaan PUAP yaitu memberikan bantuan modal usaha untuk Gapoktan pada tahun pertama, melakukan usaha simpan-pinjam pada tahun kedua, dan menumbuhkan Lembaga Keuangan Mikro Agribisnis (LKM-A) pada tahun ketiga yang akhirnya difasilitasi menjadi jajaring pembiayaan dari perbankan/lembaga keuangan. LKM-A merupakan lembaga yang memberikan jasa keuangan bagi usaha agribisnis berskala mikro di perdesaan dan merupakan salah satu unit usaha yang berada dalam satu Gapoktan. Penumbuhan LKM-A merupakan program berkesinambungan dari program PUAP karena LKM-A dibentuk bertujuan untuk memberikan solusi bagi petani agar lebih mudah mengakses dan mendapatkan pelayanan keuangan dalam rangka meningkatkan usaha mereka.

Menurut Wakarmamu (2014), faktor kritis yang perlu diperhatikan dalam pengembangan LKM sektor pertanian ada pada segi kepastian hukum kelembagaan, pengurus yang kapabel, seed capital (modal dasar) yang mendukung, usaha tani yang layak secara ekonomi, karakteristik usahatani dan pendampingan teknis nasabah/pengguna jasa layanan LKM. LKM-A juga harus memiliki tata kelola sistem manajemen keuangan yang baik agar dapat menjangkau nasabah dan memaksimalkan pendapatan usaha (Kementerian Pertanian, 2010). Indikator keberhasilan LKM-A ditinjau dari sisi kinerja sosial yaitu dapat menjangkau seluruh proses yang ada dalam lembaga termasuk penyaluran dana kepada kelompokkelompok tani.

Penelitian terdahulu yang dilakukan oleh Philippus et al. (2014) menunjukkan bahwa LKM Usaha Ekonomi Desa Simpan-Pinjam (UED-SP) Sejahtera di Desa Teluk Merbau, Kecamatan Dayun, Kabupaten Siak sudah mampu mencapai tujuan kinerja sosial dilihat dari perkembangan indikator volume pinjaman, jumlah peminjam, peminjam rumah tangga miskin, jumlah staf, sumber modal LKM, jumlah penabung dan volume tabungan, kinerja staf dan insentif serta pelatihan bagi staf. Indikator produk dan layanan belum berkembang karena hanya memiliki produk keuangan berupa layanan pinjaman dan tabungan.

Hasil penelitian Rasmi et al. (2015), kinerja sosial LKM UED-SP Bina Sejahtera belum maksimal untuk meningkatkan perkembangan volume pinjaman dilihat dari jumlah peminjam yang menurun namun indikator produktivitas staf terhadap jumlah peminjam dan volume pinjaman serta rasio insentif staf mengalami perkembangan. Peningkatan rasio insentif staf tersebut juga didorong adanya pelatihan sehingga staf memiliki tanggung jawab sosial untuk meningkatkan kinerjanya.

Berdasarkan penelitian Mujiono (2016), kinerja sosial LKM UED-SP Kabupaten Bengkalis mengalami peningkatan dilihat dari indikator jumlah pinjaman, volume pinjaman rumah tangga miskin dan jumlah peminjam menurut 
gender sedangkan jumlah staf tidak mengalami perubahan karena adanya ketentuan dari pemiliki LKM yaitu pemerintah untuk tidak menambah jumlah staf.

Saleh et al. (2013) dalam penelitiannya menunjukkan bahwa kinerja LKM-A PUAP tahun 2008, 2009 dan 2010 di Kabupaten Bantul termasuk dalam kategori cukup baik dengan penilaian kinerja yang meningkat, ditunjukkan oleh peningkatan jumlah nasabah dan penyaluran kredit serta menurunnya tingkat pembiayaan bermasalah atau Non Performing Loan/NPL.

Gapoktan di Kecamatan Dawe yang berjumlah 18 memperoleh dana BLMPUAP dalam empat tahap yaitu tahun 2008 sebanyak 7 Gapoktan, tahun 2010 terdapat 1 Gapoktan, tahun 2011 sebanyak 4 Gapoktan dan tahun 2012 sebanyak 6 Gapoktan. Pengelolaan dana BLM-PUAP oleh LKM-A yang ada di Kecamatan Dawe ada yang sudah mampu berjalan dengan baik dan ada yang belum mampu berkembang secara maksimal yang dilihat dari tingkat pengembalian kredit bermasalah yang masih tinggi sehingga perputaran modal untuk pembiayaan anggota belum berjalan dengan lancar dan akan mempengaruhi tingkat pendapatan usaha LKM-A yang akan diperoleh.

Penelitian ini bertujuan untuk menganalisis kinerja sosial, pendapatan usaha LKM-A dan hubungan antara kinerja sosial dengan pendapatan usaha LKM-A di Kecamatan Dawe, Kabupaten Kudus.

\section{METODE PENELITIAN}

Penelitian dilakukan pada tanggal 12 Februari - 5 April 2018 dengan metode survei. Penentuan sampel menggunakan metode sensus dengan seluruh LKM-A yang ada di Kecamatan Dawe, Kabupaten Kudus yang berjumlah 18 LKM-A sebagai obyek penelitian. Pemilihan lokasi penelitian dilakukan secara sengaja dengan pertimbangan bahwa Kecamatan Dawe termasuk salah satu kecamatan pertama yang mendapat dana BLM-PUAP dan secara keseluruhan sudah mampu mengelola BLM-PUAP dengan baik. Data yang dikumpulkan mencakup data primer dan data sekunder. Data sekunder yang dipakai yaitu laporan Rapat Anggota Tahunan (RAT) yang berisi laporan administrasi pengelolaan LKM-A dan perkembangannya dari tahun 2015-2016. Pengukuran kinerja sosial dilakukan dengan pendekatan MIXMarket (2009) dan Philippus et al. (2014) yang berjumlah 16 indikator yang dapat dilihat pada Tabel 1 .

Tabel 1. Indikator Kinerja Sosial LKM-A

\begin{tabular}{cl}
\hline \hline No. & \multicolumn{1}{c}{ Indikator } \\
\hline 1. & Perkembangan perguliran volume pinjaman \\
2. & Perkembangan jumlah peminjam \\
3. & Perkembangan peminjam rumah tangga miskin \\
4. & Perkembangan volume pinjaman rumah tangga miskin \\
5. & Perkembangan jumlah peminjam laki-laki \\
6. & Perkembangan jumlah peminjam perempuan \\
7. & Perkembangan sumber modal LKM-A
\end{tabular}


8. Perkembangan jenis-jenis produk dan layanan

9. Produktivitas staf terhadap jumlah peminjam

10. Produktivitas staf terhadap volume pinjaman

11. Rasio insentif

12. Jumlah dan jenis pelatihan yang berhubungan dengan manajemen

13. Jumlah staf yang mengikuti pelatihan

14. Rasio jumlah peminjam laki-laki terhadap total peminjam

15. Rasio jumlah peminjam perempuan terhadap total peminjam

16. Rasio jumlah peminjam rumah tangga miskin terhadap total peminjam Sumber: Philipus, et. Al (2014)

Data mengenai 16 indikator dan pendapatan usaha LKM-A kemudian diukur menggunakan metode skoring dengan kriteria sebagai berikut:

Tabel 2. Kriteria Skor Indikator Kinerja Sosial dan Pendapatan LKM-A

\begin{tabular}{lclll}
\hline \multicolumn{1}{c}{ Kriteria } & Skor & \multicolumn{2}{c}{ Keterangan } \\
\hline Tidak Berkembang (TB) & 1 & $\begin{array}{l}\text { Persentase } \\
\text { menurun }\end{array}$ & perkembangan $0 \%$ atau \\
Sedikit Berkembang (SB) & 2 & $\begin{array}{l}\text { Persentase perkembangan 0-50\% } \\
\text { Berkembang (B) }\end{array}$ & 3 & $\begin{array}{l}\text { Persentase perkembangan } \\
\text { lebih } 1-100 \% \text { atau }\end{array}$ \\
\hline
\end{tabular}

Perhitungan perkembangan setiap indikator menggunakan rumus berikut:

$$
\mathrm{b}=\frac{\mathrm{x}_{\mathrm{i}}-\mathrm{x}_{\mathrm{i}-1}}{\mathrm{xi}} \times 100 \%
$$

dimana:

$\mathrm{b} \quad=$ persentase perkembangan

$\mathrm{x}_{\mathrm{i}} \quad=$ nilai indikator tahun 2016

$\mathrm{x}_{\mathrm{i}-1} \quad=$ nilai indikator tahun 2015

Setelah didapatkan hasil skor setiap indikator variabel kinerja sosial dan variabel pendapatan usaha, selanjutnya dilakukan analisis deskriptif dan uji korelasi Spearman menggunakan program Micosoft Excel dan SPSS 16 untuk menganalisis hubungan kedua variabel dengan hipotesis sebagai berikut:

Ho $: \mathrm{p}=0$, artinya tidak terdapat hubungan kinerja sosial terhadap pendapatan usaha LKM-A

Ha $: p \neq 0$, artinya terdapat hubungan kinerja sosial terhadap pendapatan usaha LKM-A

Kriteria pengambilan keputusan :

Ho ditolak dan Ha diterima jika nilai sig $\leq 0,05$

Ho diterima dan Ha ditolak jika nilai sig > 0,05 
HASIL DAN PEMBAHASAN

\section{Karakteristik LKM-A}

Tabel 3. Jumlah dan Persentase LKM-A Berdasarkan Karakteristik LKM-A

\begin{tabular}{lccc}
\hline \hline No & Karakteristik & Jumlah & Persentase \\
\hline
\end{tabular}

1. Tahun terima dana BLM-PUAP

2008

2010

7

1

2011

2012

2. Jumlah kelompok tani

4-5

6-7

8-9

3. Pinjaman maksimal (rupiah)

$1.000 .000-2.500 .000$

$2.600 .000-4.000 .000$

$4.100 .000-5.500000$

1

4

6

11

4

3

15

2

1
10

5

3

$41.000-60.000$

$10.000-20.000$

$21.000-40.000$

5. Jangka waktu pinjaman (bulan)

$4-7$

$8-11$

$12-15$

6. Jasa pinjaman/bulan (\%)

$<1$

$1-1,2$

$1,3-1,5$

7. Besar pinjaman bermasalah (NPL)

$<50 \%$

$>50 \%$

\section{3}

4

11

0

8

10

13

5
44

44
56

39

6

22

33

61

22

17

83

11

6

56

28

17

17

22

61

0

72

28

Sumber: data primer (diolah), 2018

Pencairan dana BLM-PUAP di Kecamatan Dawe terbagi dalam 4 tahap yaitu tahun 2008, 2010, 2011 dan 2012. Sebanyak 39\% LKM-A sudah menerima dana BLM-PUAP mulai tahun 2008 sedangkan 56\% baru menerima dana tersebut pada tahun 2011-2012. Hal ini dikarenakan terdapat beberapa persyaratan yang harus dipenuhi oleh Gapotan untuk menerima dana BLM-PUAP. Gapoktan penerima dana BLM-PUAP di Kecamatan Dawe sudah berbentuk LKM-A namun sebagian besar masih dalam proses memiliki badan hukum kecuali 3 LKM-A yang sudah memiliki badan hukum dalam bentuk koperasi. Kepengurusan LKM-A sebagian besar masih menjadi satu dengan kepengurusan Gapoktan. 
Kredit macet atau Non-Performing Loan (NPL) merupakan persentase kredit yang tidak dapat dikembalikan oleh peminjam sesuai waktu yang disepakati. Lima LKM-A mengalami kredit macet di atas 50\% dengan 3 LKM-A diantaranya yaitu penerima dana BLM-PUAP tahun 2008. Salah satu penyebabnya yaitu LKM-A yang menerima BLM-PUAP pada awal tahun 2008 masih belum siap menerima program dan kurangnya bimbingan teknis dalam masalah pengembalian dana pinjaman. Hal ini sesuai dengan hasil penelitian Saleh et al. (2013) yang menyebutkan bahwa kinerja LKM-A penerima dana tahun 2008 relatif kurang baik ditunjukkan oleh ratarata kredit dan tingkat NPL yang relatif lebih tinggi.

Lima LKM-A dengan NPL > 50\% berada dalam kategori pinjaman Rp. 1.000.000 - Rp 2.500.000 namun 13 LKM-A lainnya dengan NPL <50\% juga menyebar dalam 3 kategori pinjaman seperti dalam Tabel 3. Hasil ini menunjukkan bahwa kredit macet yang tinggi tidak hanya disebabkan oleh semakin besarnya jumlah pinjaman yang bisa diakses oleh anggota karena LKM-A dengan pinjaman maksimal Rp. 5.000.000 justru menunjukkan NPL < 50\%. Pinjaman yang besar jika dimanfaatkan dengan baik akan dapat meningkatkan skala usaha anggota karena permasalahan kekurangan modal dapat diatasi dengan adanya kredit tersebut. Wulandari et al. (2017) berpendapat bahwa dengan adanya pemberian kredit dan modal yang tinggi akan menyebabkan pendapatan usaha kecil meningkat karena kredit yang diberikan digunakan sebagai tambahan modal kerja yang kemudian mempengaruhi pendapatan usahanya.

LKM-A dengan tingkat NPL $>50 \%$ lebih banyak berada dalam kategori jangka waktu pinjaman 12-15 bulan. Pemilihan tenggat waktu selain menyesuaikan dengan musim tanam juga perlu diperhatikan potensi risiko jika waktu yang diberikan akan menjadikan tersendatnya anggota dalam mengembalikan pinjaman. Hal ini dikarenakan adanya tenggang waktu pengembalian akan mempengaruhi suatu risiko dalam pemberian kredit seperti pinjaman bermasalah. Tenggang waktu suatu kredit yang semakin panjang akan berpengaruh pada besarnya risiko kredit (Kasmir, 2012).

\section{Kinerja Sosial LKM-A di Kecamatan Dawe}

Tabel 4. Jumlah dan Persentase LKM-A Berdasar Volume Pinjaman dan Jumlah

Peminjam serta Jumlah Peminjam dan Volume Pinjaman Rumah Tangga Miskin

\begin{tabular}{|c|c|c|c|}
\hline Indikator & "Kriteria Perkembangan & Jumlah & Persentase \\
\hline & & ----LKM-A---- & -----\%"----- \\
\hline \multirow[t]{3}{*}{ Perguliran volume pinjaman } & Tidak Berkembang & 11 & 61 \\
\hline & Sedikit Berkembang & 7 & 39 \\
\hline & Berkembang & 0 & 0 \\
\hline \multirow[t]{3}{*}{ Jumlah peminjam } & Tidak Berkembang & 14 & 78 \\
\hline & Sedikit Berkembang & 4 & 22 \\
\hline & Berkembang & 0 & 0 \\
\hline \multirow{4}{*}{$\begin{array}{l}\text { Jumlah peminjam rumah } \\
\text { tangga miskin }\end{array}$} & Tidak Berkembang & 13 & 72 \\
\hline & Sedikit Berkembang & 5 & 28 \\
\hline & Berkembang & 0 & 0 \\
\hline & Tidak Berkembang & 13 & 72 \\
\hline
\end{tabular}




\begin{tabular}{lllc}
\hline $\begin{array}{l}\text { Perguliran volume pinjaman } \\
\text { rumah tangga miskin }\end{array}$ & Sedikit Berkembang & 5 & 28 \\
\hline
\end{tabular}

Sumber: data primer (diolah), 2018

Berdasarkan data penelitian dapat dilihat bahwa 14 indikator tidak mengalami perkembangan dan hanya indikator rasio insentif dan rasio jumlah peminjam perempuan terhadap total peminjam yang mengalami perkembangan lebih dari 50\%. Indikator volume pinjaman dan jumlah peminjam tidak mengalami perkembangan dikarenakan LKM-A memberikan kebijakan untuk tidak memberikan pinjaman kepada anggota yang masih memiliki tunggakan sejak awal peminjaman modal. Hal ini akibat dari tersedianya modal yang ada di LKM-A tidak mencukupi sehingga menghambat percepatan pengembalian modal dari peminjam.

Kriteria rumah tangga miskin yang digunakan dalam penelitian ini adalah petani baik pemilik ataupun penggarap dengan lahan di bawah 0,5 ha, kegiatan pemasaran usaha kecil seperti bakulan dan industri rumah tangga pertanian dan peternakan. Rasio peminjam rumah tangga miskin terhadap total peminjam kategori sedikit berkembang terdapat 10 LKM-A atau 56\% dengan rata-rata rasio sebesar 64\%. Hal ini menunjukkan bahwa partisipasi rumah tangga miskin untuk memperoleh pinjaman sudah baik namun dapat ditingkatkan lagi agar lebih banyak rumah tangga miskin yang bisa mengakses modal untuk membantu pengembangan usahanya agar tercapai tujuan Program PUAP yaitu mengurangi kemiskinan dan pengangguran melalui penumbuhan dan pengembangan kegiatan usaha agribisnis di perdesaan.

Tabel 5. Jumlah dan Persentase LKM-A Berdasar 12 Indikator

\begin{tabular}{llcc}
\hline \hline \multicolumn{1}{c}{ Indikator } & \multicolumn{1}{c}{$\begin{array}{c}\text { Kriteria } \\
\text { Perkembangan }\end{array}$} & Jumlah & Persentase \\
\hline \multirow{3}{*}{ Jumlah peminjam laki-laki } & Tidak Berkembang & 15 & - ------ $\%$----- \\
& Sedikit Berkembang & 3 & 83 \\
& Berkembang & 0 & 17 \\
& Tidak Berkembang & 12 & 67 \\
\hline Jumlah peminjam & Sedikit Berkembang & 6 & 33 \\
perempuan & Berkembang & 0 & 0 \\
\hline Sumber modal LKM-A & Tidak Berkembang & 6 & 33 \\
& Sedikit Berkembang & 12 & 67 \\
& Berkembang & 0 & 0 \\
\hline Perkembangan jenis-jenis & Tidak Berkembang & 17 & 94 \\
produk dan layanan & Sedikit Berkembang & 1 & 6 \\
& Berkembang & 0 & 0 \\
\hline Produktivitas staf terhadap & Tidak Berkembang & 14 & 78 \\
jumlah peminjam & Sedikit Berkembang & 4 & 22 \\
& Berkembang & 0 & 0 \\
\hline Produktivitas staf terhadap & Tidak Berkembang & 11 & 61 \\
volume pinjaman & Sedikit Berkembang & 7 & 39 \\
& Berkembang & 0 & 0 \\
\hline
\end{tabular}




\begin{tabular}{llcc}
\hline Rasio insentif & Tidak Berkembang & 15 & 83 \\
& Sedikit Berkembang & 2 & 11 \\
& Berkembang & 1 & 6 \\
\hline Jumlah dan jenis pelatihan & Tidak Berkembang & 18 & 100 \\
yang berhubungan dengan & Sedikit Berkembang & 0 & 0 \\
manajeman & Berkembang & 0 & 0 \\
\hline Jumlah staf yang mengikuti & Tidak Berkembang & 18 & 100 \\
pelatihan & Sedikit Berkembang & 0 & 0 \\
& Berkembang & 0 & 0 \\
\hline Rasio jumlah peminjam laki- & Tidak Berkembang & 16 & 89 \\
laki terhadap total & Sedikit Berkembang & 2 & 11 \\
peminjam & Berkembang & 0 & 0 \\
\hline Rasio jumlah peminjam & Tidak Berkembang & 9 & 50 \\
perempuan terhadap total & Sedikit Berkembang & 8 & 44 \\
peminjam jumlah peminjam & Tidak Berkembang & 8 & 6 \\
\hline Rasio jum & Berkembang & 1 & 44 \\
rumah tangga miskin & Sedikit Berkembang & 0 & 56 \\
terhadap total peminjam & Berkembang & 0 \\
\hline
\end{tabular}

Sumber: data primer (diolah), 2018

Berdasarkan data penelitian, jumlah peminjam laki-laki pada tahun 2015 dan 2016 berturut-turut yaitu 988 dan 949 sedangkan peminjam perempuan pada tahun 2015 dan 2016 yaitu 207 dan 2018. Rasio peminjam perempuan mengalami peningkatan yang berarti bahwa pengelola LKM-A sudah mampu memberikan kesempatan kepada kaum perempuan untuk berperan aktif dalam memanfaatkan pinjaman guna menunjang kehidupan ekonomi keluarganya. Namun jika dilihat dari segi jumlah peminjam perempuan, tentu angka tersebut masih kecil sehingga harus ada upaya dari pengelola LKM-A untuk lebih mengenalkan kepada masyarakat terutama perempuan yang memiliki UMKM di bidang pertanian untuk memanfaatkan program PUAP. Pemerintah maupun masyarakat juga harus mulai menumbuhkan UMKM pertanian baru bagi wanita agar dapat membantu meningkatkan pendapatan rumah tangga. Rachmina (2009) berpendapat bahwa meningkatnya kesempatan kerja dan berusaha untuk perempuan akan diikuti oleh meningkatnya aksesbilitas perempuan terhadap kredit dan akan berdampak pada peningkatan kontribusi perempuan terhadap pendapatan dan kesejahteraan rumah tangga.

Jumlah sumber modal LKM-A kriteria sedikit berkembang ada 12 LKM-A. Komponen sumber modal ini terdiri dari cadangan modal, dana BLM-PUAP, simpanan pokok, simpanan wajib dan dana penyertaan. Modal tersebut yang digunakan untuk memenuhi kebutuhan pinjaman para anggotanya. Hendar (2014) menyatakan bahwa dengan karakteristik modal koperasi seperti ini (simpanan, pinjaman, penyisihan hasil usaha, cadangan dan sumber lain) sangat riskan terhadap berbagai krisis karena koperasi tidak memiliki dasar modal permanen yang kuat. Dengan demikian, LKM-A membutuhkan inovasi baru dengan mencari tambahan modal untuk berkembang tidak hanya bergantung pada usaha simpanpinjam, misalnya menambah layanan tabungan dan membentuk unit usaha seperti penjualan pupuk atau peralatan pertanian. 
Produk dan layanan LKM-A di Kecamatan Dawe hingga saat ini masih sebatas usaha simpan-pinjam sedangkan untuk tabungan seperti simpanan sukarela, belum ada anggota LKM-A di Kecamatan Dawe yang melakukan simpanan sukarela. Beberapa faktor penyebabnya yaitu masih sulitnya perekonomian anggota terutama peminjam rumah tangga miskin sehingga menabung belum menjadi prioritas dan belum ada rasa kepercayaan dari anggota untuk menabung di LKM-A. Sementara berdasarkan penelitian Indayani dan Ghozali (2017), tabungan memberikan pengaruh positif, hal ini memberikan keyakinan bahwa meningkatnya risiko modal akan mendisiplinkan perilaku manajer untuk bertanggung jawab menghasilkan kas dan penggunaan arus kas bebas untuk bisa menutupi biaya modal yang timbul.

Staf merupakan salah satu kunci dari keberhasilan LKM-A karena staf yang bertugas untuk mengelola keuangan dan menjaga agar tidak ada tunggakan dalam pengembalian modal pinjaman. Kepengurusan LKM-A rata-rata masih bergabung dengan kepengurusan Gapoktan contohnya bendahara Gapoktan sekaligus sebagai pengelola LKM-A dan bertugas mencatat semua transaksi dan pembuatan laporan keuangan.

Selama tahun 2015 - 2016 hanya 2 LKM-A yang mendapat pelatihan yaitu Piji Makmur dan Rejo Mulyo (Desa Cranggang). Satu orang staf LKM-A Piji Makmur pada tahun 2015 mengikuti pelatihan manajemen LKM-A di Temanggung. Pada tahun 2016, satu orang staf pengelola LKM-A Piji Makmur juga mengikuti pelatihan dari Dinas Pertanian, Perikanan dan Kehutanan Kabupaten Kudus. Pada masamasa awal program PUAP, pelatihan dan bimbingan dilakukan oleh petugas khusus atau Penyelia Mitra Tani (PMT) namun setelah program berakhir (akhir tahun 2014) pembinaan dilanjutkan oleh Penyuluh kecamatan mengingat masa kontrak PMT yang sudah habis. Pelatihan yang diberikan kepada LKM-A ini sangat bermanfaat untuk meningkatkan kemampuan manajemen organisasi pengelola mengingat karakteristik SDM petani yang masih terbatas baik dalam penguasaan manajemen maupun IPTEK. Hal ini sesuai dengan pendapat Handoko (2009) yang menyatakan bahwa latihan bertujuan untuk memperbaiki penguasaan keterampilan dan teknik pelaksanaan pekerjaan tertentu, terperinci dan rutin sehingga efisiensi dan efektivitas kerja semakin meningkat.

Berdasarkan hasil penelitian, terdapat 7 LKM-A yang memberikan insentif kepada stafnya. Insentif dalam hal ini yaitu jasa yang diberikan kepada staf yang diperoleh dari pendapatan yang diterima LKM-A sehingga pemberian insentif tersebut tergantung seberapa besar pendapatan yang diterima. Pemberian insentif ini diharapkan dapat lebih meningkatkan kinerja staf agar LKM-A dapat lebih berkembang. Menurut Arianto et al. (2015), pelibatan pegawai diperlukan dalam pengelolaan kualitas dan kuantitas portofolio kredit. Kebijakan insentif berdasar kinerja dapat meningkatkan kinerja kualitas (kredit macet dan tunggakan yang rendah) dan kuantitas (jumlah nasabah/debitur). 


\section{Pendapatan Usaha LKM-A di Kecamatan Dawe}

Tabel 6. Jumlah dan Persentase LKM-A Berdasar Pendapatan Usaha

\begin{tabular}{cccc}
\hline \hline Variabel & Kriteria Perkembangan & Jumlah & Persentase \\
\hline \multirow{3}{*}{ Pendapatan Usaha } & & ----LKM-A---- & -----\%----- \\
& Tidak Berkembang & 14 & 78 \\
& Sedikit Berkembang & 3 & 16 \\
& Berkembang & 1 & 6 \\
\hline
\end{tabular}

Sumber: data primer (diolah), 2018

Berdasarkan Tabel 6., mayoritas pendapatan usaha LKM-A di Kecamatan Dawe dalam kriteria tidak berkembang, kriteria sedikit berkembang ada 3 LKM-A dan kriteria berkembang ada 1 LKM-A. Empat LKM-A tidak mendapatkan pendapatan dikarenakan selama 2 tahun tersebut belum ada penambahan jumlah peminjam karena masih adanya kredit yang macet sehingga LKM-A masih fokus untuk proses pengembalian pinjaman dari anggota. Rata-rata pendapatan usaha yang diperoleh LKM-A di Kecamatan Dawe yaitu Rp. 6.655.662.

LKM-A Relung Muria dan Sido Mulyo mengalami penurunan volume pinjaman namun mengalami perkembangan pendapatan yang diperoleh berdasarkan hasil penelitian. Pendapatan tersebut selain didapatkan dari jasa pinjaman tahun berjalan juga diperoleh dari jasa terhutang dari pinjaman tahun sebelumnya. Sebagian besar pendapatan yang diperoleh berasal dari jasa pinjaman dari modal yang dipinjam, semakin banyak peminjam dan volume pinjaman maka tambahan jasa akan semakin besar pula dengan catatan pengembalian pinjaman dapat tepat waktu karena jasa pinjaman dibayarkan oleh anggota bersamaan dengan pengembalian pokok pinjaman. Wulandari et al. (2017) dalam hasil penelitiannya menyebutkan bahwa jumlah kredit berpengaruh positif terhadap pendapatan. Semakin tinggi jumlah kredit maka semakin tinggi pula pendapatan yang diperoleh.

Berdasarkan hasil penelitian, diketahui bahwa LKM-A yang ada di Kecamatan Dawe mengalami kredit macet di atas 5\% sehingga mempengaruhi tingkat pendapatan yang diperoleh. Hasil penelitian Wulandari et al. (2017) menunjukkan bahwa risiko kredit berpengaruh negatif signifikan terhadap pendapatan. Semakin tinggi risiko kredit maka semakin tinggi pula pendapatan.

Pendapatan lainnya yang didapat yaitu dari biaya administrasi dan pendapatan bunga dari dana yang disimpan dalam bank. Biaya administrasi diambil dari pokok pinjaman yang diberikan dan dipotong pada awal pencairan pinjaman, besarnya yaitu 1\%. Lima dari 18 LKM-A tidak menerapkan biaya administrasi yaitu Kombang Subur, Soco Bersatu, Sumber Makmur (Desa Tergo), Rejo Mulyo (Desa Cranggang) dan Sarirejo.

\section{Hubungan Kinerja Sosial dengan Pendapatan Usaha LKM-A}

Berdasarkan uji korelasi Spearman, dapat diketahui bahwa nilai signifikansi sebesar 0,280 dan nilai koefisien korelasi sebesar 0,269. Nilai signifikansi lebih besar dari 0,05 maka Ho diterima dan Ha ditolak yang berarti bahwa tidak terdapat hubungan yang signifikan antara variabel kinerja sosial dengan variabel pendapatan usaha LKM-A di Kecamatan Dawe. Hal ini menujukkan bahwa semakin besar 
jangkauan masyarakat yang bekerja di sektor pertanian baik dari segi perempuan, laki-laki maupun rumah tangga miskin tidak berhubungan dengan pendapatan usaha LKM-A. Pendapatan usaha LKM-A diperoleh dari seberapa lancarnya perguliran pinjaman dan ketepatan anggota dalam mengembalikan pinjaman beserta jasa pinjaman. LKM yang mampu mempertahankan pengaruh positifnya terhadap kesejahteraan sosial ekonomi orang miskin jika LKM tersebut memiliki kinerja keuangan dan jangkauan (outreach) yang baik (Arsyad, 2017).

\section{KESIMPULAN DAN SARAN}

\section{Kesimpulan}

Perkembangan kinerja sosial tahun 2015 - 2016 dilihat dari indikator peminjam, peminjam perempuan, peminjam laki-laki, peminjam rumah tangga miskin dan volume pinjamannya, produktivitas staf, rasio insentif staf, jenis produk dan layanan serta pelatihan staf masih dalam kriteria tidak berkembang sedangkan indikator sumber modal, rasio peminjam perempuan dan rasio peminjam rumah tangga miskin dalam kriteria sedikit berkembang. Pendapatan usaha LKM-A di Kecamatan Dawe tahun 2015 - 2016 mayoritas dalam kategori tidak berkembang dengan rata-rata pendapatan usaha yaitu Rp. 6.655.662. Tidak terdapat hubungan yang signifikan antara variabel kinerja sosial dengan pendapatan usaha LKM-A di Kecamatan Dawe.

\section{Saran}

1. Perlu adanya peningkatan pembimbingan dan pengawasan pengajuan pinjaman oleh petani sampai pemanfaatan dan pengembalian pinjaman agar mengurangi terjadinya kredit macet.

2. Pembentukan unit usaha lainnya selain unit simpan pinjam dan penambahan layanan tabungan agar ada tambahan modal.

3. Pengaktifan pengurus Gapoktan dan LKM-A dan pengurusan proses badan hukum sehingga dapat memperoleh tambahan dana dari lembaga lain.

4. Perlu usaha untuk meningkatkan kontribusi wanita misalnya dibentuk Kelompok Wanita Tani atau diberikan pelatihan usaha.

\section{DAFTAR PUSTAKA}

Arianto, D. A. N., S. Arifin, dan M. Imron. 2015. Kinerja pegawai lembaga keuangan mikro: motif pemberian insentif dan komparasi berbasis insentif. The 1st University Research Colloquium (URECOL), 152-160.

Arsyad, L. 2017. Lembaga Keuangan Mikro: Institusi, Kinerja dan Sustanabilitas. Yogyakarta: CV Andi Offset.

Hendar. 2014. Manajemen Perusahaan Koperasi. Jakarta: Erlangga.

Herwinarni dan W. Hariyanto. 2011. Kajian peran lembaga keuangan mikro agribisnis dalam pengembangan usaha agribisnis di perdesaan Kabupaten Wonosobo. Prosiding Semiloka Nasional Dukungan Agro-Inovasi untuk Pemberdayaan Petani, Kerjasama UNDIP, BPTP Jateng dan Pemprov Jateng. 33: 407-413. Semarang. 
Indayani dan I. Ghozali. 2017. Struktur modal dan keberlangsungan lembaga keuangan mikro. J. Akuntansi dan Auditing Indonesia, 21(2): 81-94.

Kasmir. 2012. Bank dan Lembaga Keuangan Mikro Lainnya. Jakarta: PT. Raja Grafindo Persada.

Kementerian Pertanian. 2010. Petunjuk Teknis Pemeringkatan (Rating) Gapoktan PUAP menuju LKM-A. Jakarta: Kementerian Pertanian.

Kementerian Pertanian. 2016. Pedoman Pemberdayaan dan Penguatan LKM-A Tahun Anggaran 2016. Jakarta: Kementerian Pertanian.

MIXMarket. 2009. Social Performance Standards Report. Diambil 17 April 2017, dari https://www.themix.org/publications/mix-microfinanceworld/2010/07/social-performance-report

Mujiono. 2016. Eksistensi lembaga keuangan mikro dan dampaknya terhadap sosial ekonomi masyarakat Kabupaten Bengkalis. J. Inovasi dan Bisnis. 4(2): 156171.

Philippus, A. Rifai, dan R. Yulida. 2014. Analisis kinerja sosial dan kinerja keuangan Lembaga Keuangan Mikro (LKM) Usaha Ekonomi Desa Simpan-Pinjam (UEDSP) Sejahtera Desa Teluk Merbau Kecamatan Dayun Kabupaten Siak. Jom. Faperta. 1(2): 1-14.

Rachmina, D. 2009. Fenomena kesetaraan gender dalam kredit. J. Agribisnis dan Ekonomi Pertanian. 3(1): 1-18.

Rasmi, A. K., A. Rifai, dan E. Tety. 2015. Analisis kinerja sosial dan kinerja keuangan Usaha Ekonomi Desa-Simpan Pinjam (UED-SP) Bina Sejahtera di Desa Sibabat Kecamatan Siberida Kabupaten Indragiri Hulu Provinsi Riau. Jom. Faperta. 2(1): 1-14.

Saleh, Y., C. Sugihono, dan V. W. Hanifah. 2013. Kinerja lembaga keuangan mikro agribisnis di Kabupaten Bantul Provinsi Yogyakarta. J. Pengkajian dan Pengembangan Teknologi Pertanian. 16(3): 212-222.

Handoko, T.H. 2009. Manajemen. Yogyakarta: BPFE.

Wakarmamu, T. 2014. Eksistensi lembaga keuangan mikro dalam pembangunan ekonomi pedesaan. J. Kajian Ekonomi dan Studi Pembangunan. 1(3), 1-18.

Wulandari, N. M. M., M.A. Wahyuni, dan I. P. G. Diatmika. 2017. Pengaruh jumlah kredit, tingkat suku bunga kredit, risiko kredit dan tenaga kerja terhadap pendapatan pada Koperasi Kredit Swastiastu periode 2012-2015. e-journal S1 Akuntansi. 7(1), 1-11. 